\title{
Polycyclic Aromatic Hydrocarbons for the Soil-plant-Environment System
}

\author{
Ryuji TAKEDA*, Yoshimasa IKUMA*, Sadayoshi MATSUMOTO*, \\ Sadao KOMEMUSHI ${ }^{*}$ and Akiyoshi SAWABE* \\ "Department of Agricultural Chemistry, Faculty of Agriculture, Kinki University \\ Nakamachi 3327-204, Nara 631-8505, Japan Fax: +81-742-43-1445 \\ E-mail: sawabe@nara.kindai.ac.jp
}

\begin{abstract}
Polycyclic aromatic hydrocarbons (PAHs) are ubiquitous environmental contaminants found in air, sea and river water and soil. Sources of PAHs are thought to include diesel, fossil fuels and power plants. Some PAHs are known to be carcinogenic and mutagenic. Phytoremediation of PAHs is defined as the use of plants and their associated bacteria to remediate contaminated soil. These processes occur on rhizosphere. Plants excrete exudate associated with bacterial activity.

The relationship of vegetation to PAH concentration was investigated. Two and 3 rings of PAHs, showed high volatility and were not related to vegetation. However, areas with extensive vegetation had lower concentrations of 4 to 6 rings of PAHs.

Plant responses of pyrene were investigated by superoxide dismutase (SOD) activity. Some plants were collected from sampling spots and steeped in pyrene dissolved in water or distilled water. Most plants showed greater increase in SOD activity when placed in pyrene dissolved in water than when placed distilled water. Especially, Artemisia princeps showed a high level of SOD activity (68.3\%). This finding suggested that the substances with high SOD activity participated in degradation of PAHs.
\end{abstract}

Key words: Artemisia princeps, PAHs, Phytoremediation, Rhizodegradation, Soil,

\section{Introduction}

Polycyclic aromatic hydrocarbons (PAHs) are ubiquitous environmental contaminants found in air, sea and river water and soil. They occur as common constituents of gasoline, coal tar and shale oil, but are most frequently formed by incomplete combustion of fossil fuels (Maila and Cloete, 2002; Pothuluri and Cerniglia, 1994). Therefore, these substances are longlasting, poorly degradable pollutants, that accumulate in the environment. Furthermore, these substances present a great affinity for organic materials in soil such as humus. Some PAHs are known to be carcinogenic and mutagenic (Laflamme and Hite, 1978; Pahlman and Pelkonen, 1987). Especially, benzo(a)pyrene is known as an endocrine disrupter (Liu and Korenaga, 2001). Sixteen PAHs have been selected by the US Environmental Protection Agency (EPA) as Constant Decree priority pollutants for regulatory purposes (Hodgeson, 1990). The potential for atmospheric concentrations of PAHs to accumulate in many geographical locations of the world have been determined and reported, e.g., Massachusetts, USA (Allen et al., 1996), Athens, Greece (Viras et al., 1987), Mumbai, India (Kulkarni and Venkataraman, 2000), Lahore, Pakistan (Smith et al., 1996), and Kuala Lumpur, Malaysia (Omar et al., 2002). However, there is still very little information on the concentration of these substances in soil.
The remediation of organic pollutants uses physical and chemical techniques. The cost however is very expensive and requires significant labor. The solution of this problem is bioremediation and phytoremediation. Bioremediation is a technique by which pollutants are biodegraded by bacteria. It has been reported that white rot fungi can extensively biodegrade PAH(Bumpus, 1989; Zheng and Obbard, 2002), because white rot fungi are capable of nonspecifically oxidizing aromatic compounds through the abstraction of an electron or a hydrogen atom. (Barr and Aust, 1994; Hattaka, 1994). Phytoremediation is the process by which contaminants in the environment are removed by plants (Cunningham et al., 1996). The targets of phytoremediation are various pollutants, e.g. heavy metals, NOx, SOx, agricultural chemicals and PAHs. Enhancement of PAH degradation in soil rhizosphere has been shown in several studies (Aprill and Sims, 1990; Binet et al., 2000; Qiu et al., 1994; Reilley et al., 1996). Grasses are being used due to their fibrous root systems with extensive surface area for microbial colonisation (Adam and Duncan, 2002).

The studies and investigations have not provided sufficient information regarding the relationship between soil PAHs and vegetation.

In this study, we investigated the relationship between vegetation and PAHs concentration and the responses of weeds with large biomass and poor environmental adaptation to contact with PAHs. 


\section{Materials and Methods}

\subsection{Concentrations of 16 US EPA-identified PAHs in soils}

Soil was collected from various spots in highly trafficked and vegetated areas, as well as three spots around our university. Collected soils were sieved with a $2.0 \mathrm{~mm}$ nylon mesh sieve. There were extracted PAHs from $5.0 \mathrm{~g}$ of soil by soxhlet extraction with $120 \mathrm{ml}$ of dichloromethane. These extractions processes were repeated three times. Extracted solutions were condensed to $1.0 \mathrm{~mL}$ by an evaporator using $\mathrm{N}_{2}$. The concentrations of $16 \mathrm{PAHs}$ were determined by HPLC analysis. HPLC determination was performed using a Shimadzu Co, Ltd. LC-10AT binary pump and SPD-10A UV/VIS detector. Column and analytical parameters were as follows

Column: $25 \mathrm{~cm} \times 4.6 \mathrm{~mm}$ i.d. stainless steel.

analytical column packed with $5 \mu \mathrm{m}$

Supercosil LC-PAH (Superco).

Analytical parameters: $5 \mathrm{~min}$ after starting analysis, linear gradient elution from 40: 60 acetonitrile/water to $100: 0$ acetonitrile/water $35 \mathrm{~min}$ after starting analysis. The temperature of the column was 23 degrees, flow rate was $1.0 \mathrm{ml} / \mathrm{min}$ and detection wavelength was $254 \mathrm{~nm}$. Injection volume was $5.0 \mu \mathrm{L}$.
2.2 Collection of plant root exudates and measurement SOD activity

Plants were collected at the same sampling points for investigation of PAH concentrations. Collecting plants were washed with distilled water to remove soil. The plants were steeping in $300 \mathrm{ml}$ of pyrene solution $(0.035 \mathrm{mg} / \mathrm{l}$ dissolved in distilled water) or in $300 \mathrm{ml}$ of distilled water. After 72 hours, these root exudates were collected and freeze dried. And these exudates were dissolved in distilled water at $1000 \mu \mathrm{g} / \mathrm{mL}$

Superoxide scavenging activity was determined by NBT reduction with a WAKO SOD kit (WAKO Pure Chemical Ind. Ltd.). A mixture $(230 \mu \mathrm{L})$ of exudates sample $(10 \mu \mathrm{L})$, nitroblue tetrazonium $\left(\mathrm{NO}_{2}-\mathrm{TB}\right)$ solution, xanthin solution, xanthinoxidase and superoxide dismutase was incubated at $37^{\circ} \mathrm{C}$ for 28 min, Sidium dodecyl sulfate was then added to the mixture and absorbance was measured at $560 \mathrm{~nm}$.

\section{Results and Discussion}

Table 1 indicates the concentrations of 16 PAHs at different vegetated and trafficked sampling sites. Heavy traffic caused higher concentrations of total PAHs. However, sites with extensive vegetation in the same trafficked area had lower concentrations of total PAHs. When classified by the number of benzene rings, vegetation greatly influenced the number of rings. Since 2- and 3-ring PAHs have higher volatility, these did not remain in soil, while 4to 6-ring PAHs more easily remained in soil, and were degraded by plant and bacteria.

Table 1 Concentration of total and rings number of PAHs (mean \pm S.D.) at different spot $(n=3)$.

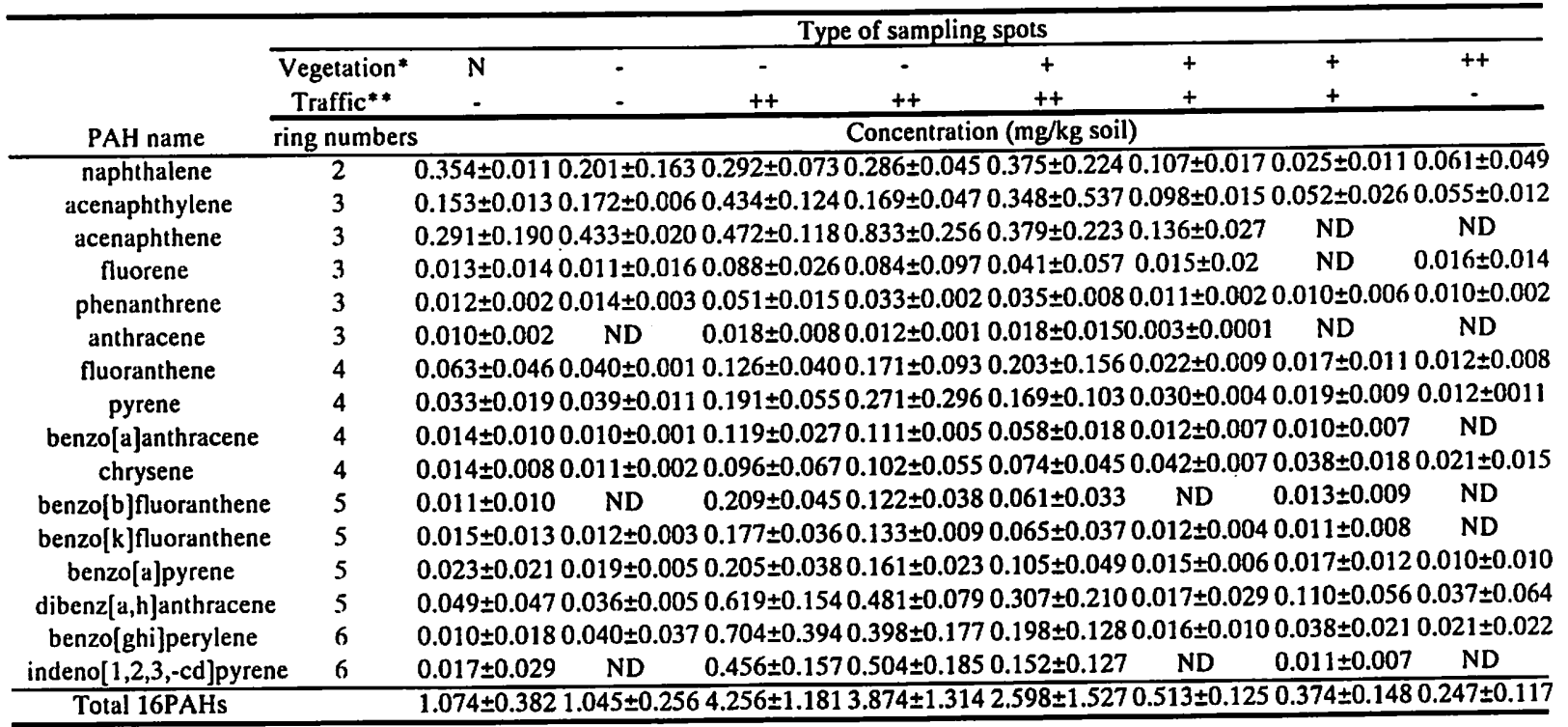

$*++:$ It is covered the whole surface vegetation. $+: 70 \%$ are covered vegetation. $-:$ Less than $50 \%$ are covered vegetation.

**++: $>5000 \mathrm{cars} /$ day, +: 500-5000 cars/day, -: $<500$ cars/day

N: No vegetation

ND: Less than detected limit $(0.010 \mathrm{mg} / \mathrm{kg}$ soil) 
Table 2 indicates the SOD activity of plant exudates. (The concentration of plant exudates was $1000 \mathrm{ppm}$.) Most plants showed higher SOD activity when placed in pyrene dissolved in water than when placed in distilled water. Especially, Artemisia princeps showed very high SOD activity (68.3\%).

The interaction between plants and bacterial communities is a complex relationship. Plants sustain large bacterial populations in the rhizosphere by rhizodeposition (Paul and Clark, 1989). The excretion of root exudates by plants contributes to increasing the density of bacteria found near the plant root. Therefore, root exudates have previously been found to enhance biodegradation of organic compounds. Mineralization of the organophosphate insecticide parathion was stimulated in soil by the addition of bush bean root exudates, but not to the extent observed in the plant system (Hsu and Bartha, 1979).

Plants have genetically controlled mechanisms that allow them to live and grow under stress. (Boyer, 1982) This study showed plant responses to organic pollutants such as PAHs, although root exudates differed by plant species. Niyogi et al., 2001 were investigated of relationships with accumulated PAHs concentration and antioxidant enzymes in barnacle tissues of Balanus balanoides. They were indicated that tissue concentrations of PAHs, resulting in a significant positive correlation with antioxidant enzymes, mainly catalase and SOD. Example in plants, SOD-over-expressing alfalfa and tobacco tolerant to environmental stresses (e.g. water and high light) was shown (McKersie et al., 1996; Van Camp et al., 1996; Alscher et al., 2002). This finding suggests that substances with high SOD activity by participate in the degradation of PAHs.

Table 2. SOD activity of plant exudates(n=3).

\begin{tabular}{ccc}
\hline plant name & solution type & SOD activity $(\%)^{*}$ \\
\hline Artemisia princeps & distilled water & $9.1 \pm 1.2$ \\
& pyrene dissolved & $68.3 \pm 3.6$ \\
Chenopodium album & distilled water & $22.2 \pm 1.5$ \\
& pyrene dissolved & $11.9 \pm 2.2$ \\
Solidago altissima & distilled water & $16.1 \pm 3.4$ \\
& pyrene dissolved & $36.8 \pm 3.3$ \\
Fatoua villosa & distilled water & $7.8 \pm 2.3$ \\
& pyrene dissolved & $13.1 \pm 1.5$ \\
Amaranthaus viridis & distilled water & $6.1 \pm 0.2$ \\
& pyrene dissolved & $15.3 \pm 1.3$ \\
\hline
\end{tabular}

- This activities indicate supesuxide scavenging activities that was determined hy NBT reduction each sample concentration was $1000 \mu \mathrm{g} / 1 \mathrm{~mL}$

\section{References}

Adam, G. and Duncan, H. 2002: Influence of diesel fuel on seed germination. Environ. Pollu., 120, 363370.

Allen, J. O. Dookeran, N. M., Smith, K. A., Taghizaden, K. and Lafleur, A. L., 1996:
Measurement of polycyclic aromatic hydrocarbons associated with sizesegregated atmospheric aerosols in Massachusetts. Environ. Sci. Tech., 30, 10231031.

Alscher, R. G., Erturk N. and Heath L. S. 2002: Role of Superoxide dismutases (SODs) in controlling oxidative stress in plants. J. Exp. Bot., 53, 13311341.

Aprill, W. and Sims, R. C. 1990: Evaluation of the use of prairie grasses for stimulating polycyclic aromatic hydrocarbon treatment in soil Chemosphere, 20, 253-265.

Barr, D. P. and Aust, S. D., 1994: Mechanisms white rot fungi use to degarade pollutants. Critical Reviews of Environ. Sci. Tech., 28, 78A-87A.

Binet, Ph., Portal, J.M. and Leyval, C., 2000: Fate polycyclic aromatic hydrocarbons (PAHs) in the rhizosphere and mycorrhizosphere of ryegrass. Plant and Soil, 227, 207-213.

Boyer, J. S., 1982: Plant productivity and environment, Science., 218, 443-448.

Bumpus, J. A., 1989:Biodegradation of polycyclic aromatic hydrocarbons by Pharnerochaete chrysosporium. App.Environ. Microbio., 55, 154158.

Cunningham, S. D., Anderson, T. A., Schwab, A. P. and Hsu, F. C., 1996: Phytoremediation of soils contaminated with organic pollutants. Adv. Agro., 56, 55-114.

Hattaka, A., 1994: Lignin-modifying enzymes from selected white-rot fungi: production and role in lignin degradation. FEMS Microbio., Rev. 13, 125 135.

Hodgeson, J. W., 1990: Polynuclear Aromatic Hydrocarbons. US Environmental Protection Agency, Cincinnati, $\mathrm{OH}, 143 \mathrm{pp}$.

Hsu, T. S. and Bartha, R., 1979: Accelerated mineralization of two organophosphate insecticides in the rhizosphere. App. Environ. Microbio., 37, 3641.

Kulkarni, P. and Venkataraman, C., 2000: Atmospheric polycyclic aromatic hydrocarbons in Mumbai, India. Atmos. Environ., 34, 2785-2790.

Laflamme, R. E. and Hite, R. A., 1978: The global distribution of polycyclic aromatic hydrocarbons in recent sediments. Geo. Cosmo. Acta., 42, 289-303.

Liu, X. and Korenaga, T., 2001: Dynamic Analysis for the Dsitribution of Polycyclic Aromatic Hydrocarbons in rice. J. Heal. Sci., 45, 446-451.

Maila, M. P. and Cloete, T. E., 2002: Germination of Lepidium sativum as a. method to evaluate polycyclic aromatic hydrocarbons (PAHs) removal from contaminated soil. International Biodet.Biodeg., 50, 107-113.

McKersie, B. D., Bowley, S. R., Harjanto, E. and Leprince O., 1996: Water-deficit tolerance and field performance of transgenic alfalfa overexpressing superoxide dismutase. Plant Physiol., 111, 11771181. 
Niyogi, S., Biswas, S., Sarker, S. and Datta, A. G., 2001: Seasonal variation of antioxidant and biotransformation enzymes in barnacle, Balanus balanoides, and their relation with polyaromatic hydrocarbons. Marine Env. Res., 52, 13-26.

Omar, N. Y. M. J., Abas M. R. B., Ketuly, K. A. and Tahir, N. M., 2002: Concentration of PAHs in atmospheric particles (PM-10) and roadside soil particles collected in Kuala Lumpur, Malaysia. Atmos. Environ., 36, 247-254.

Pahlman, R. and Pelkonen, O., 1987: Mutagenecity studies of different polycyclic aromatic hydrocarbons. The significance of enzymatic factors and molecular structyres. Carcinogenesis., 8, 773778.

Paul, E. A. and Clark F. E., 1989: Soil Microbiology and Biochemistry. Academic Press, New York, $275 \mathrm{pp}$.

Pothuluri, J. V. and Cerniglia, C. E., 1994: Microbial metabolism of cyclic aromatic hydrocarbon. Dioscorides Press, Portland, OR, 92pp.

Qiu, X., Shah, S. I., Kendall, E. W., Sorensen, D. L., Sims, R. C. and Engelke, M. C., 1994: Grassenhanced bioremediation for clay soils contaminated with polynuclear aromatic hydrocarbons. In Bioremediation Through Rjizosphere Technorogy (eds. by T. A. Anderson and J. R. Coats), American Chemical Society, Washington DC, pp. 28-42.
Reilley, K. A., Banks, M. K. and Schwab, A. P. 1996: Dissipation of polycyclic aromatic hydrocarbons in the rhizosphere. J. Environ. Qual., 25(2),212-219

Smith, D. J. T., Harrison, R. M., Luhana, L., Castro C. A., Tariq M. N., Hayat, S. and Quraishi, T., 1996: Concentrations of particulate airborne polycyclic aromatic hydrocarbons and metals collected in Lahore, Pakistan, Atmos. Environ., 30, 4031-4040.

Van Camp, W., Capiau, K., Van Montagu, M., Inzé, D. and Slooten, L., 1996: Enhancement of oxidative stress tolerance in transgenic tobacco plants overproducing Fe-superoxide dismutase in chloroplasts. Plant Physiol., 112, 1703-1714.

Viras, L. G., Siskos, P. A. and Stephanou, A. E. 1987: Determination of polycyclic aromatic hydrocarbons in Athens atmosphere. Int. J. Environ. Anal. Chem., 28, 71-85.

Zheng, Z. and Obbard, J. P., 2002: Removal of surfactant solubilized polycyclic aromatic hydrocarmons by Phanerocaete chrysosporium in a rotating biological contactor reactor. J. Biotech., 96, 241-249. 